\title{
A review on scope of immuno-modulatory drugs in Ayurveda for prevention and treatment of Covid-19
}

\author{
Srivastava Niraj $^{{ }^{*}} \&$ Saxena Varsha ${ }^{2}$ \\ ${ }^{1}$ Department of Kaumarbhritya / Bal-Roga, Sardar Patel Institute of Ayurvedic Medical Sciences \& Research, Lucknow 226 301, India \\ ${ }^{2}$ Department of Shalya-tantra, Main Campus, Uttarakhand Ayurveda University (UAU), Dehradun 248 001, India \\ *Email: nirajimsbhu@gmail.com
}

\section{ARTICLE HISTORY}

Received: 05 June 2020

Accepted: 13 July 2020

Published: 18 July 2020

KEYWORDS

SARS-CoV-2

Rasayana dravyas

Ashwagandha

Suvarna prashana

AYUSH-64

\begin{abstract}
The Coronavirus disease 2019 (COVID-19) is caused by severe acute respiratory syndrome Coronavirus-2 (SARS CoV-2) infection attacking mainly on the immune system of a body. It is a potentially fatal disease that is of public health and economy concern globally. In December 2019, COVID-19 outbreak occurred in Wuhan city, Hubei Province, China furthermore spread worldwide. Research is underway in many countries to develop effective vaccines and drugs for the COVID-19. In Ayurveda, Acharya Charaka explained the concept of an epidemic condition in Janapadodhwansa Adhayay and combating of these diseases is to be done by Panchakarma (five procedures of purification), Rasayana Chikitsa (immune-modulators therapy) and Sadvritta (good conduct). Rasayan dravyas (immunomodulator drugs) of Ayurveda can be used for health promotion, immune-modulation, prevention and reduce disease burden from COVID-19. Drugs such as Ashwagandha (Withania somnifera (L.) Dunal), Guduchi (Tinospora cordifolia (Willd.) Miers), Amalaki (Phyllanthus emblica L.), Mulethi (Glycyrrhiza glabra L.), Shatavari (Asparagus racemosus Willd.), Chireta (Andrographis paniculata (Burm.f.) Nees), Tulsi (Ocimum sanctum L.) Punarnava (Boerhaavia diffusa L.) and Pippali (Piper longum L.) For symptom management of COVID-19 like illness Agastya Haritaki, Anutaila, AYUSH-64 can be used. Scientific research on these drugs may reveal the new approach for the prevention and management of COVID-19. The main aim of this article is to review research which has already conducted and currently being carried out on the herbal plant for their immunomodulation property which have a possible application in the prevention and treatment of COVID-19.
\end{abstract}

\section{Introduction}

From the beginning of the 21st century, three coronaviruses have caused grievous outbreaks of respiratory origin in human beings. Severe acute respiratory syndrome coronavirus (SARS-CoV) in 2002, Middle-East respiratory syndrome coronavirus (MERS-CoV) in 2012 and at present COVID-19 is the third coronavirus pandemic (1). In December 2019 this RNA virus first reported in the Wuhan City, Hubei province in China and within three month spread to nearly 72 countries and presently reported to occur in 188 countries and territories around the world. The World Health Organization (WHO) declared this disease as pandemic on 11 March 2020 (2). In a very short period COVID-19 has caused destabilizing health systems and economy around the world. The first case of COVID-19 in India was a student who returned from Wuhan, China on January 30, 2020 (3). On March 31, 2020, Ministry of AYUSH has issued an advisory note on a variety of immunityenhancing steps, supported by literature of Ayurveda, scientific publications and time tested approaches to resist SARS-CoV-2 infection by enhancing the-immune response of the body (4). For any circumstances prevention from diseases is better than cure so modulation of immune responses by any measures may become beneficial in reducing disease aggravation and mortality rate. Now, India has a chance proving its traditional system of medicine by developing evidence-based prophylactic and curative strategies based on Ayurveda.

The concept of pandemic disease is mentioned by Acharya Charaka in Janapadodhwansa Chapter $3^{\text {rd }}$ in Vimana sthana. Acharya Charaka explained

(C) Niraj \& Varsha (2020). This is an open-access article distributed under the terms of the Creative Commons Attribution License, which permits unrestricted use, distribution and reproduction in any medium, provided the original author and source are credited (https://creativecommons.org/licenses/by/4.0/).

To cite this article: Niraj S, Varsha S. A review on scope of immuno-modulatory drugs in Ayurveda for prevention and treatment of Covid-19. Plant Science Today 2020;7(3):417-423. https://doi.org/10.14719/pst.2020.7.3.831 
that Vayu (air), Jala (water), Desh (soil \& area) and Kala (time) are four responsible factors for group infection in the community and further described the whole concept of managing pandemic situation (5). For any epidemic condition Panchakarma (five procedures of purification), Rasayana Chikitsa (immune-modulators therapy) and Sadvritta (good conduct) are leading treatments in Ayurveda (5). Among these the foremost treatment is the Rasayana Chikitsa. There are several compounds and herbs having the Rasayana effect. Rasayana drugs enriches the basic Dhatu i.e. Rasa which further resulted in Sapta Dhatus of optimum quality and hence, body, soul and mind gets their nourishment. Rasayana dravyas is mentioned for groups of important drugs that supposed to improve defence mechanism and enhance longevity (6). Rasayana may be used in two ways, either as a prophylactic medicine or as a preventive measure in healthy people (7). Human immune system is complex and there lies a delicate balance between health and disease. Any substance, synthetic or biological, which can enhance, suppress or modulate the immune system is called an immunomodulator drugs. Till date many of the Rasayana dravyas are known for their immunomodulatory effects via modulation of cytokine secretion, histamine release, immunoglobulin secretion, lymphocyte secretions and phagocytosis and so on (8). Therefore, Rasayana dravyas such as Ashwagandha (Withania somnifera (L.) Dunal), Guduchi (Tinospora cordifolia (Willd.) Miers), Amalaki (Phyllanthus emblica L.), Mulethi (Glycyrrhiza glabra L.), Shatavari (Asparagus racemosus Willd.), Chireta (Andrographis paniculata (Burm.f.) Nees), Tulsi (Ocimum sanctum L.) Punarnava (Boerhaavia diffusa L.) Pippali (Piper longum L.) and other Ayurvedic measures like Swarna prashana for children can be potential drugs for providing preventive, supportive and rehabilitative care in the treatment of COVID-19 patients by modulating the immune system.

In this review, the concept of epidemic diseases and Rasayana in Ayurveda, a brief overview of COVID-19, mechanism of action of the SARS-CoV-2 infection in the human host cell and the potential use of certain Ayurvedic herbs for the effective treatment of COVID-19 has been discussed. Through this review, we suggest that Ayuvedic Rasayan dravyas (immuno modulatory drugs) may be a beneficial step to combat viruses like the SARS-CoV-2 due to its antiviral and immunomodulatory properties.

\section{Materials and Methods}

For information on SARS-CoV-2 and COVID-19, authors searched major scientific databases namely Pubmed, Science Direct, Google Scholar, Springer and Elsevier for the most recent information regarding the pandemic. The search words used were 'SARS-CoV-2', 'COVID-19', 'Immunopathology' and immunomodulatory and antiviral herbal drug for COVID-19, bioactive compounds' along with the names of drugs, according to their use. Classical textbooks of Ayurveda (Charaka Samhita and The Ayurvedic Pharmacopeia of India) are reviewed for documenting the information about Janapadodhwansa and Rasayan dravyas. The articles published during 2002-2020 were included in the manuscript.

\section{Results}

\section{Concept of Epidemics and Immunomodulatory drugs in Ayurveda:}

An epidemic is a disease that affects a large number of populations within a community or region and the pandemic is an epidemic that's spread over multiple countries at the same time. Knowledge of microorganism and epidemics are described in the classical textbook of Ayurveda. Acharya Sushruta describes that the diseases like Kustha (skin disease), Jwara (fever), Shosha (tuberculosis) Netrabhishyanda (conjunctivitis) are contagious and consider as Aupasargika rogas (9). They are spread through direct contact or contaminated objects of a patient. Acharya Charaka has coined the term Janapadodhwansa which means the destruction of a population living in an area that same as the epidemic condition. Janapadodhwansa occurs due to vitiation of Vayu (air), Jala (Water), Desh (soil \& area) and Kala (Time).They are nothing but modes by which infectious diseases spread from one place to another. Combating of these diseases is to be done by Panchakarma, Rasayana Chikitsa (immunemodulators therapy) and Sadvritta (good conduct) (5). Ayurveda also has a concept of Agantuja Vyadhi (exogenous diseases) and the term Agantuja Vyadhi is implied for all diseases which may be due to external trauma or organisms such as parasites, viruses, bacteria, fungi etc. (10) So COVID-19 can be treated as Agantuja Vyadhi as this is a viral infection. Rasayana can be a drug, diet or even a life style and conduct which improves the state of nourishment, increased immunity and youthfulness. Ayurveda describes Rasayana drugs as having which claimed to have immunomodulatory and antiviral properties (11).

\section{A brief overview of COVID-19:}

COVID-19 is a respiratory pandemic caused by severe acute respiratory syndrome Coronavirus-2 (SARS-CoV-2). SARS-CoV-2 has 96.2\% structural similarity with bat coronavirus and $79.5 \%$ similarity with severe acute respiratory syndrome coronavirus (SARS-CoV) (12). Coronaviruses have a single stranded RNA genome covered by an enveloped structure (13). Size ranges of Coronaviruses are 26.2 - 31.7 kilobases (kb) and 50-200 nanometres in diameter which is the largest for any RNA viruses. The SARS-CoV-2 spike protein directly binds with the host cell surface ACE2 receptor facilitating virus entry and replication. SARS-CoV-2 uses ACE2 as a cellular entry receptor and has 10-20 times more affinity as compared to SARS-CoV, leading to more chances of human-to-human transmission (14). A key question is why the lungs the most susceptible target organ. One reason is huge surface area, which 
makes the lungs highly susceptible to inhaled viruses and another that $83 \%$ of ACE2 cells are available at alveolar epithelial type II cells (AECII) (15). Mortality rate of SARS-CoV-2 is lesser (average 3.4\%) than SARS -CoV (9.6\%) and MERS -CoV (35\%) (16). Common clinical features of COVID-19 include fever (99\%), dry cough (60\%), myalgia (44\%), fatigue (70\%) and breathlessness still in advanced stages ARDS, kidney failure and even death can occur (17). Ideal laboratory confirmation of a suspected case includes nasopharyngeal and oropharyngeal swabs. Nasopharyngeal (NP) swab has become the preferred swab as it is tolerated better by the patient, safe to operate. SARS-CoV-2 RNA was detected in only $32 \%$ of OP swabs, which was significantly lower than the level in nasal swabs (63\%) (18). At present confirmation of cases of COVID-19 is based on real-time reverse transcriptase polymerase chain reactions (RT-PCR) with confirmation by nucleic acid sequencing (19). COVID -19 patients can discharge from hospital if they show two negative PCR samples from the throat within 24 hrs (20).

\section{SARS-CoV-2 and the immune system:}

SARS-Co-V-2 has four structural proteins: Spike (S), Envelop (E), Membrane (M) and Nucleocapsid (N) in which the first three are the viral envelop and RNA genome is packaged by the nucleocapsid $(\mathrm{N})$ protein (13). For replication Coronavirus needs a host in the form of a living cell. SARS-CoV-2 mainly alters immune regulatory mechanism and damage immune homeostasis (21). The immune response of SARS-CoV-2 infection occurs in two phases:

\section{Defence phase}

When Aerosolized uptake of SARS-CoV-2 enters in lungs which leads to infection of ACE2 expressing target cells such as alveolar type 2 cells. This phase generates antibody-secreting cells, helper T-cells and activated CD4, CD8 T-cells that bind to SARSCoV-2. The innate immune response against viral infection relies on the interferon (IFN) type I and control replication of the virus. SARS-CoV and SARSCoV-2 share the same cell receptor in the human entry as angiotensin-converting enzyme 2 (ACE2) but MERS-CoV uses another specific receptor dipeptidyl peptidase and amino peptidase $\mathrm{N}$ (22).

\section{Damage phase}

Lead to the uncontrolled release of cytokine that causing cytokine release syndrome(CRS), or 'cytokine storm' characterized by increased Interleukin 2 (IL-2), Interleukin 7 (IL-7), IFN-gamma, tumor necrosis factor (TNF)-alpha4 etc. Cytokine release syndrome (CRS) damages tissues of the lungs, kidney and heart that is likely lead to severe complication like acute respiratory distress syndrome (ARDS), respiratory failure and death. Cytokine storm and lymphopenia may have a significant role in the pathogenesis of SARS-CoV-2 infection (23). TH1/TH2 cytokine levels as an indicator of disease progression in human and its Restoration establish immune homeostasis (24). Cytokines are the hormonal messengers responsible for immune response and are further subdivided into Th1 and Th2 which varies according to age. Besides the immune system, another important system involve with COVID-19 is the nervous system and develop neurological symptoms, including headache, disturbed consciousness and paresthesia (25).

\section{A Possible approach to the prevention and management of COVID-19 through Ayurveda:}

At present, there are no specific antiviral drugs or vaccines verified to be effective against COVID-19; hence the stress is being laid mainly on preventive measures and symptomatic treatment (26). In the twenty one century the applications of herbal drugs to maintain health and prevention from diseases are gaining immense attention around the world. According to WHO approximately 4 billion people $(80 \%)$ of the world currently depends on herbal medicine for some aspect of primary health care (27). In Ayurveda, Rasayana dravyas are known for their immunomodulation and rejuvenation properties, which may be important in the prevention and management of COVID-19. Clinically, immunomodulatory drugs can be classified into Immunoadjuvant (enhancement of vaccine efficacy), Immunostimulants (enhancements of body's immunity through innate as well as adaptive immune responses) and Immunosuppressants (suppress the immune system in organ transplant and autoimmune diseases) (28). Numerous Rasayana drugs demonstrated the immunomodulatory effects in vitro and clinical studies such as Ashwagandha (Withania somnifera (L.) Dunal), Guduchi (Tinospora cordifolia (Willd.) Miers), Amalaki (Phyllanthus emblica L.) etc.

\section{Ashwagandha (Withania somnifera (L.) Dunal)}

Ashwagandha known as Indian winter cherry and Indian ginseng is one of the most important herbs in Ayurveda and used for the immunomodulation, combating infectious agents, management of stress and improves good physical and mental health. Ashwagandha enhances nitric oxide synthetase activity of the macrophages, which help in improving immune cells. Withania somnifera glycoprotein (WSG) is a potent source of antimicrobial activity (29). Ashwagandha helps to restore immune homeostasis by providing immune-suppression or immune stimulation effects. Ashwangandha provides anti-viral immunity by increasing Interferon gamma (IFNgamma responses) and anti-inflammatory activities by decreasing the quantity of Interleukin -1 , Interleukin -6 and Tumor necrosis factor which are the main factors related to COVID-19. Ashwangandha may be an effective agent in the management of COVID-19 infection by modulation of host Th-1/Th-2 immunity. Ashwagandha extract gives competent protective immune responses when added with DPT (Diphtheria, Pertusis, Tetanus) vaccine against fatal outcome of diphtheria and pertussis toxins (30). Ashwagandha helps enhancement of immunogenicity and constructive effect on symptoms in conjunction with anti-tuberculosis drugs used as a directly observed treatment, short-course (DOTS) (31). 


\section{Guduchi (Tinospora cordifolia (Willd.) Miers)}

Guduchi is one of the best Rasayana and known as "Amrita" means rejuvenate dead cells and have immuno-modulatory and enhances innate immunity against COVID-19 infections. Tinosporin, diterpenoid has very effective anti-viral property especially for the treatment of retroviruses and other viral diseases (32). Aqueous extracts $T$. cordifolia has influenced the cytokine production and activation of immune effector cells (33). Guduchi is a potent hepato-protective so effective in preventing in hepatotoxicity. It enhances the level of vitamin C and thus functions as an antioxidant (34). Guduchi stem has immunomodulatory protein which increases the number of macrophages and its phagocytic activity (35). Sanshamani Vati (also called Guduchi ghana vati) which contains aqueous extract of $T$. cordifolia can be adviced as $500 \mathrm{mg}$ twice a day, 15 days with warm water as a preventive and prophylactic drug for COVID-19 (36).

\section{Amalaki (Phyllanthus emblica L.)}

Amalaki is a rich source of vitamin C (Ascorbic acid) (37). Acharya Charaka has described that Amalaki is the best rejuvenating herb (38) and useful in relieving cough and skin diseases (39). Amalaki improves both cell mediated and humoral immune response. It enhances IL-2, gamma -IFN and natural killer (NK) cell activity. Amalaki is a well-known drug for its anti-oxidant, detoxification and antiaging activity (40). $P$. emblica has an antibacterial effect on Gram-negative and Grampositive organisms due to the presence of flavonoids component. Antimicrobial activity of flavonoids is probably due to the ability to form complex with extracellular and soluble proteins, or with bacterial cell walls which disrupts the microbial membranes (41). Pulmonary antioxidant defences are widely distributed in lungs and include both enzymatic and non-enzymatic systems. The primary non-enzymatic antioxidants are membrane-bound vitamin $\mathrm{C}$ and vitamin E. Amalaki is the richest source of vitamin C (42).

\section{Mulethi (Glycyrrhiza glabra L.)}

The major photo components reported in Mulethi (Yashtimadhu) is glycyrrhizin which is promising candidates in inhibiting replication of the SARSassociated virus (43). Mulethi (Yashtimadhu) improves the resistance against the herpes simplex virus type 1 (HSV-1) by Type I and II interferons (IFN) and Th2 cytokines secretion (44). It has antiviral activity against Human immunodeficiency virus (HIV), potent immunomodulatory and antioxidant activity (45).

\section{Shatavari (Asparagus racemosus Willd.)}

Shatavari is an important Ayurvedic rejuvenating tonic for the female, as Ashwagandha (Withania somnifera) for the male. Shatavari has a potent immunomodulatory property by altering the function of macrophages (46). It has immunoadjuvant potential with Diphtheria, Tetanus, Pertussis (DPT) vaccine by significant upregulation of Th-1, Th-2 and cytokines and immuno- stimulation property by significant increase of CD4/ CD8 along with T cell activation (47).

\section{Kalmegha (Andrographis paniculata (Burm. f.) Nees)}

Kalmegha is an important Ayurvedic drug which has the capacity to treat viral respiratory infections and enhance the immune response. It has viricidal activity against Herpes simplex virus 1 (HSV-1) and HIV by a significant rise in the mean $\mathrm{CD}^{+}$ lymphocyte level (48). Andrographolides, the main ingredient of $A$. paniculata enhance immune system such as the production of white blood cells, release of interferon and activity of the lymph system. The lymph carries away the by-products of cellular metabolism and acts as a shuttle for invading bacteria and viruses. The wide tissue and organ distribution and the immune-stimulating and regulatory actions of Kalmegha make it an ideal candidate in the prevention and treatment of many diseases and conditions (49).

\section{Tulsi (Ocimum sanctum L.)}

Tulsi is regarded as mother medicine of nature and it shortens the course of all illness. Tulsi has antibacterial, anti-viral and anti-fungal activity (50). A decoction of the leaves of Tulsi is beneficial for the treatment of respiratory disorders (bronchitis, asthma, influenza, cough and cold) (51). Flavonoids present in the extracts of Tulsi leaves have been found to be responsible for the immunomodulatory properties by the increased level of IL-4, natural killer cells and helper cells (52). The essential oils like Eugenol of Tulsi leaves produce anti-viral activity against different viruses e.g. polio virus type 3 , herpes virus (HSV), hepatitis B virus etc. (53) Ethanolic extract of Tulsi plant leaves in a range of $22.5 \mathrm{mg} / \mathrm{ml}$ concentration inhibit replication of polio type 3 virus. The extracted components of Tulsi like linalool and ursolic acid has shown broad- spectrum antiviral activity against DNA viruses like RNA virus and adenoviruses (54).

\section{Punarnava (Boerhaavia diffusa L.)}

Punarnava has immunomodulatory effects due to its immunosuppressive and immunostimulatory activity (55). Administration of Punarnava significantly reduced the elevated levels of proinflammatory cytokines such as TNF-alpha, IL-1beta, and IL-6 in mice. These results indicate the immunomodulatory activity of Punarnava (56). Extracts of $B$. diffusa roots have anti-inflammatory activity by inhibiting natural killer (NK) cell, cytotoxicity, production of nitric oxide in human and very high antiviral activity (57).

\section{Pippali (Piper longum L.)}

Pippali Rasayana, a famous Ayurvedic preparation, reported having significantly activated macrophages in an experimental study on mice. Administration of $P$. longum extract and its phytochemical piperine increased the total WBC count, Bone marrow cellularity and a-esterase positive cells in mice (58). Immunomodulatory action of Pippali fruits (via modulation of both specific and non-specific immune response) has been reported by using 
macrophage migration index (MMI), haemagglutination titre (HA) and phagocytic index (PI) in mice. The effect was more prominent at a lower dose $(225 \mathrm{mg} / \mathrm{kg})$ and was marginally reduced when the dose was increased (59). Pippali Rasayana, a famous Ayurvedic preparation, reported to activating macrophages significantly in mice, infected with Giardia lamblia as shown by an increased MMI and phagocytic activity.

\section{Swarna-prashana:}

'Suvarna-prashana' (SP) is also a Rasayan mentioned by Acharya Kashyap in Kashyapa Samhita, Sutra Sthana, Lehadhyaya (60) but the use of Suvarna (Gold) is generally mentioned by many Acharyas for administration during the early infantile period for improvement of memory, digestion and immunity. Suvarna-prashana is a preventive measure which acts probably via the process of immunomodulation. In the procedure of Suvarnaprashana, gold is rubbed on a white stone with the help of the little amount of water and is administered along with honey and ghee. In some places, Swarna Bhasma is administered to newborn babies with honey and ghee and some other drugs like Vacha (Acorus calamus L.), Brahmi (Bacopa monnieri (L.) Wettst) and Shankhapushpi (Convolvulus pluricaulis Choisy) etc. (61) Swarna- collaborative work on four Ayush formulations. These formulations are Ashwagandha, Yashtimadhu (Mulethi), Guduchi + Pippali and AYUSH-64. The competitive study is also planned between Hydroxychloroquine and Ashwagandha for a highrisk population (63).

\section{Conclusion}

Coronavirus disease 2019 (COVID-19) has emerged as the most hazardous pandemic risk throughout the world since its outbreak during December 2019. It has become a big challenge for the researchers to find a solution for this deadly epidemic because SARS-CoV-2 has a high rate of mutagenesis. SARSCoV-2 mainly alters immune regulatory mechanism and damage immune homeostasis. Viral infections induce oxidative stress and cause damage to airway epithelial cells. Cytokine release syndrome (CRS) or 'cytokine storm, damages tissues of the lungs, kidney and heart that in future lead to severe complication like ARDS, respiratory failure, shock and potentially death.

Ayurveda recommends prophylaxis measures for respiratory diseases that may be beneficial in COVID-19 prevention. In Ayurveda, 'Rasayan

Table 1. Ongoing clinical trials in Ayurveda for COVID-19

\begin{tabular}{|c|c|c|c|}
\hline Drug & Ingredients & Dose & Indication \\
\hline Tab. AYUSH -64 & $\begin{array}{l}\text { Saptaparna stem bark (Alstonia scholaris (L.) R. Br.), Katuki roots } \\
\text { (Picrorhiza kurroa Royle ex Benth.), Chirayata whole plant } \\
\text { (Swertia chirata Buch.-Ham. ex Wall.) and Kuberaksha seed } \\
\text { (Caesalpinia crista L.) (64) }\end{array}$ & 2 tablets twice a day. & $\begin{array}{l}\text { Respiratory } \\
\text { infections }\end{array}$ \\
\hline $\begin{array}{l}\text { Agastya Haritaki churna } \\
\text { (powder) }\end{array}$ & $\begin{array}{l}\text { Haritaki ( Terminalia chebula Retz.), Dashamoola, Pippali ( Piper } \\
\text { longum L.) etc. (65) }\end{array}$ & $\begin{array}{l}5 \text { grams twice a day with } \\
\text { warm water. }\end{array}$ & $\begin{array}{l}\text { Respiratory } \\
\text { infections }\end{array}$ \\
\hline Anuthaila (oil) & $\begin{array}{l}\text { Anutaila consists of a } 27 \text { ingredient like } \\
\text { Sesame oil, Vidanga (Embelia ribes Burm.f), Ajadugdha (goat } \\
\text { milk) etc. (66) }\end{array}$ & $\begin{array}{l}2 \text { drops in each nostril } \\
\text { daily morning. }\end{array}$ & $\begin{array}{l}\text { Respiratory } \\
\text { infections }\end{array}$ \\
\hline
\end{tabular}

prashana can be administered in all children because it acts at the level of nutrition, growth and development, physical strength and immunity. An experimental on mice showed that it improves nonspecific immune responses and stimulatory effect on peritoneal macrophages, which may be helpful to fight against infections (62).

Appropriate exploration of herbal drugs is urgently needed for prophylactic and treatment solutions to COVID-19.

\section{Symptomatic treatment from Ayurveda:}

AYUSH neither has claimed effective treatment for Corona virus nor any specific drug to combat for COVID-19. Some classical formulations such as Sudarshan Ghana vati and Sanshamani vati are used as safer symptomatic measures for conditions such as coryza and fever. AYUSH recommended some Ayurvedic drugs for symptoms management of COVID-19 like illness described in (Table 1).

\section{Ongoing clinical trials:}

For validation of Ayurvedic formulation, against COVID-19, the AYUSH Ministry and the Council of Scientific and Industrial Research (CSIR) has started dravyas' are described which concerned with nourishing the body, boosting immunity and modulators of the immune system. Some of the Rasayanas are scientifically validated and found to have the immunomodulatory effect like Aswagandha (Withania somnifera (L.) Dunal), Amalaki (Phyllanthus emblica L.), Tulasi (Ocimum sanctum L.), Guduchi (Tinospora cordifolia (Willd.) Miers), Pippali (Piper longum L.) etc. Since many Indian medicinal plants exhibit antiviral, antiinflammatory and antioxidant properties, it may be favorable to consider them for the treatment of COVID-19. Standard clinical trials should be carried out to scientifically prove its efficacy.

\section{Acknowledgements}

SN acknowledge the Uttarakhand Ayurveda University (Main campus), Harrawala, (Dehradun), Uttarakhand, for providing library facility.

\section{Authors' contributions}

All authors contributed equally. 


\section{Conflict of interests}

The authors declare that they have no conflict of interest.

\section{References}

1. Civljak R, Markoti A, Kuzman I. The third coronavirus epidemic in the third millennium: what's next? Croatian Medical Journal. 2020;61(1):1-4. https://doi.org/10.3325/cmj.2020.61.1

2. Cucinotta D, Vanelli M. WHO Declares COVID-19 a Pandemic. Acta Bio Med [Internet]. 2020 Mar 19 [cited 2020 Jul 13]; 91(1):157-60. https://doi.org/10.23750/abm.v91i1.9397

3. Sahasranaman A, Kumar N. Network structure of COVID-19 spread and the lacuna in India's testing strategy. Available at SSRN 3558548. 2020. https://doi.org/10.2139/ssrn.3558548

4. Ministry of AYUSH. Ayurveda's immunity boosting measures for self care during COVID 19. 2020, available from https://www.mohfw.gov.in/pdf/ImmunityBoostingAYUSHAdvis ory.pdf

5. Pandey Gangasahay, editor. Pt. Kashinath Sastri Vidhyotini Hindi commentarator of Charaka Samhita of Agnivesha- $1^{\text {st }}$ Vol. Viman Sthan chapter 3 verse 8. Varanasi: Chaukumba Sanskrit Sansthan; 2006. p. 445.

6. Satyapal Singh, Byadgi PS, Tripathi JS, Rai NP. Clinical appraisal of immunomodulators in Ayurveda in the light of recent pharmacological advances. World J Pharm Res. 2015;4 (4):678-92.

7. Chauhan VP, Dutt B, Vyas M, Gupta SK. Effect of immunemodulators (Rasayana Dravya) in Janapadodhwansa WSR to COVID-19. J Ayu Herb. 2020;6(1):26- 29.

8. Kumar VP, Kuttan R, Kuttan G. Effect of "Rasayanas" a herbal drug preparation on cell mediated immune responses in tumor bearing mice. Indian J Exp Biol. 1999; 37(1):23-26.

9. Vaidya Yadavji Trikamji Acharya, editor. Shri Dalhanacharaya Nibandhasamgraha commentarator of Sushruta Samhita, Nidan Sthan Kushthadhyaya (5/33-34), Chaukumba Sanskrit Sansthan, Varanasi. 2009; p. 211.

10. Agnivesha, Charaka Samhita elaborated by Charaka and Drudhabala with Ayurveda-Deepika Commentary by Chakrarapanidatta, edited by Vaidya Jadavaji Trikamji Acharya, Varanasi, Chaukhambha Surbharati Prakashan, Reprinted 2011, Vimana sthana chapter 6, verse no.3, p. 252.

11. Tripathi JS, Singh RH. The concept and practice of immunomodulation in Ayurveda and the role of Rasayanas as immunomodulators. Ancient Science of Life. 1999;19(1-2):5963.

12. Nikhat S, Fazil M. Overview of COVID-19; its prevention and management in the light of Unani medicine. Science of the Total Environment. 2020. Vol 728:138859. https://doi.org/10.1016/j.scitotenv.2020.138859

13. Yang $H$, Bartlam M, Rao Z. Drug design targeting the main protease, the Achilles' heel of coronaviruses. Current Pharmaceutical Design. 2006;12(35):4573-90. https://doi.org/10.2174/138161206779010369

14. Zhang H, Penninger JM, Li Y, Zhong N, Slutsky AS. Angiotensinconverting enzyme 2 (ACE2) as a SARS-CoV-2 receptor: molecular mechanisms and potential therapeutic target Intensive Care Medicine. 2020; 46(4):586-90. https://doi.org/10.1007/s00134-020-05985-9

15. Zhao Y, Zhao Z, Wang Y, Zhou Y, Ma Y, Zuo W. Single-cell RNA expression profiling of ACE2, the putative receptor of Wuhan COVID-19. $\quad$ BioRxiv 2020.01.26.919985. https://doi.org/10.1101/2020.01.26.919985

16. Guo YR, Cao QD, Hong ZS, Tan YY, Chen SD, Jin HJ, et al. The origin, transmission and clinical therapies on coronavirus disease 2019 (COVID-19) outbreak-an update on the status. Mi Med Res. 2020; 7(1):11. https://doi.org/10.1186/s40779-02000240-0
17. Huang C, Wang Y, Li X, Ren L, Zhao J, Hu Y, et al. Clinical features of patients infected with 2019 novel coronavirus in Wuhan, China. The Lancet. 2020;395(10223):497-506 https://doi.org/10.1016/S0140-6736(20)30183-5

18. Tang YW, Schmitz JE, Persing DH, Stratton CW. Laboratory diagnosis of COVID-19: current issues and challenges. Journal of Clinical Microbiology. 2020;58(6);12-20. https://doi.org/10.1128/JCM.00512-20

19. Padhi A, Kumar S, Gupta E, Saxena SK. Laboratory diagnosis of novel coronavirus disease 2019 (COVID-19) infection. In: Coronavirus Disease 2019 (COVID-19) 2020 (pp. 95-107). Springer, Singapore. https://doi.org/10.1007/978-981-15-48147_9

20. Tsang OT, Chau TN, Choi KW, Tso EY, Lim W, Chiu MC, et al Severe acute respiratory syndrome: relapse? Hospital infection? Emerging infectious diseases. 2003; 9(9):1180-81. https://doi.org/10.3201/eid0909.030395

21. Patwardhan B, Chavan-Gautam P, Gautam M, Tillu G, Chopra A, Gairola S, et al. Ayurveda rasayana in prophylaxis of COVID19. Curr Sci. 2020;118:1158-60.

22. Kindler E, Thiel V, Weber F. Interaction of SARS and MERS coronaviruses with the antiviral interferon response. Adv Virus Res. 2016; 96:219-43. https://doi.org/10.1016/bs.aivir.2016.08.006

23. Wong CK, Lam CW, Wu AK, Ip WK, Lee NL, Chan IH et al. Plasma inflammatory cytokines and chemokines in severe acute respiratory syndrome. Clinical \& Experimenta Immunology. $\quad 2004 ; \quad 136 \quad$ (1):95-103. https://doi.org/10.1111/j.1365-2249.2004.02415.x

24. Osakwe CE, Bleotu C, Chifiriuc MC, Grancea C, Otelea D, Paraschiv S, et al. TH1/TH2 cytokine levels as an indicator for disease progression in human immunodeficiency virus type 1 infection and response to antiretroviral therapy. Roum Arch Microbiol Immunol. 2010;69(1):24-34

25. Wu Y, Xu X, Chen Z, Duan J, Hashimoto K, Yang L, Liu C, Yang C. Nervous system involvement after infection with COVID-19 and other coronaviruses. Brain Behav Immun. 2020; 87: 18-22. https://doi.org/10.1016/j.bbi.2020.03.031

26. Jean SS, Lee PI, Hsueh PR. Treatment options for COVID-19: The reality and challenges. I Microbiol Immunol Infect. 2020; 43(3):436-43. https://doi.org/10.1016/j.jmii.2020.03.034

27. Hashemi SR, Davoodi H. Herbal plants as new immunostimulator in poultry industry: a review. Asian Journal of Animal and Veterinary Advances. 2012;7(2):105-16. https://doi.org/10.3923/ajava.2012.105.116

28. Mahima , Anu Rahal, Rajib Deb, Shyma K. Latheef, Hari Abdu Samad, et al. Immunomodulatory and Therapeutic Potentials of Herbal, Traditional/Indigenous and Ethnoveterinary Medicines. Pakistan Journal of Biological Sciences. 2012; 15(16):754-74. https://doi.org/10.3923/pjbs.2012.754.774

29. Tiwari R, Chakraborty S, Saminathan M, Dhama K, Singh SV. Ashwagandha (Withania somnifera): Role in safeguarding health, immunomodulatory effects, combating infections and therapeutic applications: A review. Journal of Biological $\begin{array}{llll}\text { Sciences. } & \text { 2014; } & 14 & \text { (2):77-94 }\end{array}$ https://doi.org/10.3923/jbs.2014.77.94

30. Gautam M, Diwanay SS, Gairola S, Shinde YS, Jadhav SS, Patwardhan BK. Immune response modulation to DPT vaccine by aqueous extract of Withania somnifera in experimental system. International immunopharmacology. 2004;4(6):841-9. https://doi.org/10.1016/j.intimp.2004.03.005

31. Kumar R, Rai J, Kajal NC, Devi P. Comparative study of effect of Withania somnifera as an adjuvant to DOTS in patients of newly diagnosed sputum smear positive pulmonary tuberculosis. Indian Journal of Tuberculosis. 2018; 65 (3):246 51. https://doi.org/10.1016/j.ijtb.2017.05.005

32. Akhtar S. Use of Tinospora cordifolia in HIV infection. Indian $\begin{array}{lll}\text { Journal of 2010;42(1):57. } & \text { Pharmacology. }\end{array}$ https://doi.org/10.4103/0253-7613.62402

33. Upadhyaya R, Pandey RP, Sharma V, Verma Anita K Assessment of the multifaceted immunomodulatory potential of the aqueous extract of Tinospora cordifolia. Research Journal of Chemical Sciences. 2011;1(6):71-79. 
34. Mainzen Prince PS, Padmanabhan M, Menon VP. Restoration of antioxidant defence by ethanolic Tinospora cordifolia root extract in alloxan-induced diabetic liver and kidney. Phytotherapy Research: An International Journal Devoted to Pharmacological and Toxicological Evaluation of Natural Product Derivatives. 2004;18(9):785-87. https://doi.org/10.1002/ ptr.1567

35. Aranha I, Clement F, Venkatesh YP. Immunostimulatory properties of the major protein from the stem of the Ayurvedic medicinal herb, guduchi (Tinospora cordifolia). Journal of ethnopharmacology. 2012;139 (2):366-72 https://doi.org/10.1016/j.jep.2011.11.013

36. Ministry of AYUSH, Advisory from ministry of Ayush for meeting the challenge arising out of spread of corona virus (COVID-19) in India. 2020. Available from: https://www.ayush.gov.in/docs/125.pdf

37. Pandey Gangasahay (editor). Pt. Kashinath Sastri Vidhyotini Hindi commentarator of Charaka Samhita of Agnivesha- 1st volume, Sutra Sthan chapter 25 verse 40. Varanasi: Chaukumba Sanskrit Sansthan; 2006. p.201.

38. Pandey Gangasahay, editor. Pt. Kashinath Sastri Vidhyotini Hindi commentarator of Charaka Samhita of Agnivesha- 1s volume, Sutra Sthan chapter 4 verse 11-13. Varanasi: Chaukumba Sanskrit Sansthan; 2006. p.88.

39. Sharma R, Martins N, Kuca K, Chaudhary A, Kabra A, Rao MM, Prajapati PK. Chyawanprash: A traditional Indian bioactive health supplement. Biomolecules. 2019;9(5):161. https://doi.org/ 10.3390/biom9050161

40. Saini A, Sharma S, Chhibber S. Protective efficacy of Emblica officinalis against Klebsiella pneumoniae induced pneumonia in mice. Indian Journal of Medical Research. 2008;128 (2):18893.

41. Tsuchiya H, Sato M, Miyazaki T, Fujiwara S, Tanigaki S, Ohyama M, Tanaka T, Iinuma M. Comparative study on the antibacterial activity of phytochemical flavanones against methicillin-resistant Staphylococcus aureus. Journal of Ethnopharmacology. 1996;50(1):27-34. https://doi.org/10.1016/0378-8741(96)85514-0

42. Repine JE, Bast AA, Lankhorst ID, Oxidative Stress Study Group. Oxidative stress in chronic obstructive pulmonary disease. American Journal of Respiratory and Critical Care $\begin{array}{llll}\text { Medicine. } & 1997 ; & 156 & (2): 341-57 .\end{array}$ https://doi.org/10.1164/ajrccm.156.2.9611013

43. Cinatl J, Morgenstern B, Bauer G, Chandra P, Rabenau H, Doerr HW. Glycyrrhizin, an active component of liquorice roots and replication of SARS-associated coronavirus. The Lancet. 2003; $361 \quad$ (9374):2045-46 https://doi.org/10.1016/S0140 6736(03)13615-X

44. Wang L, Yang R, Yuan B, Liu Y, Liu C. The antiviral and antimicrobial activities of licorice, a widely-used Chinese herb. Acta Pharmaceutica Sinica B. 2015;5(4):310-15. https://doi.org/10.1016/j.apsb.2015.05.005.

45. Akamatsu H, Komura J, Asada Y, Niwa Y. Mechanism of antiinflammatory action of glycyrrhizin: effect on neutrophil functions including reactive oxygen species generation. Planta Medica. 1991; 57(02):119-21. https://doi.org/10.1055/s-2006960045

46. Dahanukar S, Thatte U, Pai N, Mose PB, Karandikar SM. Protective effect of Asparagus racemosus against induced abdominal sepsis. Indian Drugs. 1986; 24(3):125-28.

47. Gautam M, Diwanay S, Gairola S, Shinde Y, Patki P, Patwardhan B. Immunoadjuvant potential of Asparagus racemosus aqueous extract in experimental system. Journal of

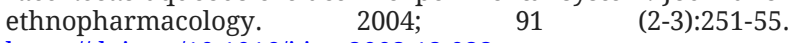
https://doi.org/10.1016/j.jep.2003.12.023

48. Naik SR, Hule A. Evaluation of immunomodulatory activity of an extract of andrographolides from Andographis paniculata. Planta Medica. 2009 Jun; 75(08):785-91. https://doi.org/10.1055/ s-0029-1185398

49. Carr RR, Nahata MC. Complementary and alternative medicine for upper-respiratory-tract infection in children. American Journal of Health-System Pharmacy. 2006; 63(1):33-39. https://doi.org/10.2146/ajhp040613
50. Cohen MM. Tulsi-Ocimum sanctum: A herb for all reasons. Journal of Ayurveda and Integrative Medicine. 2014; 5 (4):25159. https://doi.org/10.4103/0975-9476.146554

51. Pattanayak P, Behera P, Das D, Panda SK. Ocimum sanctum Linn. A reservoir plant for therapeutic applications: An Overview. Pharmacognosy Reviews. 2010;4(7):95105.https://doi.org/10.4103/0973-7847.65323

52. Mondal S, Varma S, Bamola VD, Naik SN, Mirdha BR, Padhi MM, Mehta N, Mahapatra SC. Double-blinded randomized controlled trial for immunomodulatory effects of Tulsi (Ocimum sanctum Linn.) leaf extract on healthy volunteers. Journal of Ethnopharmacology. 2011;136(3):452-56. https://doi.org/10.1016/j.jep.2011.05.012

53. Ravi V, Parida S, Desai A, Chandramuki A, Gourie-Devi M, Grau GE. Correlation of tumor necrosis factor levels in the serum and cerebrospinal fluid with clinical outcome in Japanese encephalitis patients. Journal of Medical Virology. 1997; 51(2):132-36. https://doi.org/10.1002/(SICI)10969071(199702)51:2<132::AID-JMV8>3.0.CO;2-8

54. Sangeetha P, Poornamathy JJ. In vitro assessment of antiinflammatory activity of Ocimum sanctum (karunthulas leaves). Int Pharma Bio Sci. 2015;6:B1387-91.

55. Mungantiwar AA, Nair AM, Shinde UA, Dikshit VJ, Saraf MN, Thakur VS, et al. Studies on the immunomodulatory effects of Boerhaavia diffusa alkaloid fraction. Journal of Ethnopharmacology. 1999; 5(2):125-31. https://doi.org/10.1016/ S0378-8741(98)00153-6

56. Manu KA, Kuttan G. Immunomodulatory activities of Punarnavine, an alkaloid from Boerhaavia diffusa. Immunopharmacology and Immunotoxicology. 2009;31(3):37787. https://doi.org/10.1080/08923970802702036

57. Awasthi LP, Verma HN. Boerhaavia diffusa-A wild herb with potent biological and antimicrobial properties. Asian AgriHistory. 2006;10(1):55-68.

58. Sunila ES, Kuttan G. Immunomodulatory and antitumor activity of Piper longum Linn. and piperine. Journal of Ethnopharmacology. https://doi.org/10.1016/j.jep.2003.10.016

59. Khushbu C, Roshni S, Anar P, Carol M, Mayuree P. Phytochemical and therapeutic potential of Piper longum Linn. A review. International Journal of Research in Ayurveda and Pharmacy. 2011;2(1):157-61.

60. Jyothy KB, Sheshagiri S, Patel KS, Rajagopala S. A critical appraisal on Swarnaprashana in children. Ayu. 2014, 35(4):361. https://doi.org/10.4103/0974-8520.158978

61. Raj GR, Shailaja U, Sagar K, Viswaroopan D, Kumar SN Swarnaprashana to Swarnamritaprashana: experience inspired modification through ages. International Journal of Pharmaceutical Sciences and Research. 2017;8(11):4546-50.

62. Bajaj S, Ahmad I, Raisuddin S, Vohora SB. Augmentation of non-specific immunity in mice by gold preparations used in traditional systems of medicine. Indian J Med Res. 2001;113:192-96

63. Ministry of Ayurveda, Yoga \& Naturopathy, Unani, Siddha and Homoeopathy (AYUSH), Government of India, 2020, available from: https://health.ncog.gov.in/ayush-covid-dashbaord

64. Central Council for Research in Ayurvedic Sciences (CCRAS), 2014, available from: http://www.ccras.nic.in/sites/default/files/ viewpdf/IEC_Communication/Ayush\%2064.pdf

65. Pandey Gangasahay (editor). Pt. Kashinath Sastri Vidhyotini Hindi commentarator of Charaka Samhita of Agnivesha- $2^{\text {nd }}$ Vol. Chikitsa Sthan chapter 18 verse 57-60. Varanasi: Chaukumba Sanskrit Sansthan; 2006. p.237-38.

66. Pt Harisadashiva shastri paradakara, editor. Sarvang sundar commentary by Arundatta and Ayurveda rasayan commentary by Hemadri of Astang Hridya of Vagbhata, Sutra Sthan Adhayay chapter 20 verse 38-39, Chaukhambha Surbharati Prakashan Reprinted, Varanasi. 2011; p.293-94. 